\title{
ANALYSIS OF THE USEFULNESS OF DISTINCTIVE NOISE FEATURES FROM RAIL AND WHEEL IN ASSESSING THEIR IMPACT ON THE OVERALL RAILWAY NOISE LEVEL
}

\author{
Tadeusz WSZOŁEK ${ }^{1}$, Justyna MAJCHROWICZ ${ }^{2}$ \\ ${ }^{1}$ AGH University of Science and Technology, Department of Mechanics and Vibroacoustics \\ tadeusz.wszolek@agh.edu.pl \\ ${ }^{2}$ AGH University of Science and Technology, justynamajchrowicz1@gmail.com
}

\begin{abstract}
The interaction of the wheel and rail is the main source of railway noise over a wide speed range. The relationship between wheel and rail noise on the overall level depends on the pass-by speed, with the dominance of noise from the rail at low speeds and the reverse relationship at higher speeds. Therefore, as part of the work the issue of analyzing the characteristic features of the acoustic signal generated on a selected section of the railway line from three different passenger trains TLK, Stadler and Pendolino was taken. The spectra of LEQ levels and their spread in 1/3 octave bands and spectral moments were adopted as the main distinctive features. The degree of aggregation of permanent features assigned to the track and variable features characteristic for passing-by trains were analysed. There were also tested their usefulness in the assessment of the impact of noise from wheels and rails on the overall level of railway noise from the tested units. The obtained results confirm the usefulness of the features based on the analysis of the spread of results in $1 / 3$ octave bands in differentiating noise sources from rail and wheel, with slightly less usefulness of spectral moments.
\end{abstract}

Keywords: Railway noise, distinctive noise features, spectral moments, cluster analysis, acoustical measurements

\section{ANALIZA PRZYDATNOŚCI CECH DYSTYNKTYWNYCH HAŁASU OD SZYNY I KOŁA W OCENIE ICH WPŁYWU NA POZIOM OGÓLNY HAŁASU KOLEJOWEGO}

\section{Streszczenie}

Interakcja koła z szyną jest głównym źródłem hałasu kolejowego w szerokim zakresie prędkości. Relacja pomiędzy wpływem hałasu od koła i szyny na poziom ogólny zależy od prędkości przejazdu, z dominacją hałasu od szyny przy niskich prędkościach i relacji odwrotnej przy prędkościach wyższych. Dlatego w ramach pracy podjęto zagadnienie analizy cech dystynktywnych sygnału akustycznego generowanego na wybranym odcinku linii kolejowej od trzech różnych jednostek - pociągów osobowych TLK, Stadler oraz Pendolino. Jako główne cechy przyjęto widma poziomów LEQ i ich rozrzuty w czasie przejazdu w pasmach $1 / 3$ oktawy oraz momenty widmowe. Analizowano stopień agregacji cech stałych przypisanych do torowiska oraz cech zmiennych charakterystycznych dla przejeżdżających pociągów i ich przydatności w ocenie wpływu hałasu od kół i szyn na poziom ogólny hałasu kolejowego od badanych jednostek na danym odcinku. Otrzymane wyniki potwierdzają niezłą przydatność cech opartych o analizę rozrzutu wyników w pasmach 1/3 oktawy w różnicowaniu źródeł hałasu od szyny i koła, przy nieco mniejszej przydatności momentów widmowych.

Słowa kluczowe: hałas kolejowy, cechy dystynktywne hałasu, momenty widmowe, analiza skupień, pomiary akustyczne

\section{INTRODUCTION}

The main source of railway noise in the range of speed below $300 \mathrm{kph}$ is the rolling noise, although in the lowest quantities of this parameter, below $50 \mathrm{kph}$ the traction noise has to be considered [12]. The main source of the rolling noise are the vibrations caused by the irregularities of the rail and the surface of the wheel. The vibrations of the wheel propagate through to the bogie and the construction of a carbody. On the other hand the vibrations of the rail propagates throughout the sleepers and substructure (ballast and subrage). Two of the mentioned kinds of vibrations are the sources of acoustic waves with the range of various frequencies and amount of energy [13]. The vibrations of wheels could be connected with their eigenmodes with the dominant concentration of vibration energy in the range of frequencies above $1600 \mathrm{~Hz}$, while the emission of acoustic waves being generated by the rail between 250 $1250 \mathrm{~Hz}$ [12]. The noise having its source in vibrating sleepers could be connected with the frequencies below $500 \mathrm{~Hz}$. However there are publications that describe different divisions of such bands of frequencies [1,8]. Nonetheless there is a common agreement that higher frequencies are generated by the wheel, but lower by the track.

Considering the emission of the noise to the environment, the sound levels from both of the noise sources (wheel and rail) have to be taken under 
consideration $[3,6,9]$. However because of the homologation procedures it is important to divide those two factors. The need to separate the mentioned noise sources caused the process of investigations and researches in order to find the effective method [17].

One of the first is the MISO (Multiple Input Single Output) method in which the rail emission level is estimated based on measurements of rail vibrations and noise in the near field and the function of the transition between these quantities. The level emitted by the wheel and the chassis is the difference between general noise and rail noise [8].

Another way is the VTN (Vibroacoustic Track Noise) method with the use of TWINS (Track-Wheel Interaction Noise Software) models for the emission of acoustic energy from the running gear as well as the rail and track $[6,14,18]$. One of the currently used PBA (Pass-by Analysis [10]) methods is based on the construction of a transition matrix used to separate the effect of roughness levels (rail and wheel) based on the measurement of rail vibrations and the sound pressure level defined in ISO3095 [21].

In publication [10], the four levels of differentiation of rolling noise sources were distinguished, starting from level 0 - no differentiation possible, level 1 - noise differentiation from rail and wheel, level 2 - noise differentiation from rail, wheel, roughness of rail and wheel and finally level 3 - including additional consideration of track and vehicle dynamic interactions. The tests were carried out on the same tracks using the same rolling stock, which was considered sufficiently to ignore dynamic interactions. Level 2, i.e. the differentiation of noise from rail, wheel and wheel and rail roughness, was adopted as the target. Rail roughness, wheel roughness and train speed are the main factors for rolling noise emissions.

The level of noise emissions from the running gear and the superstructure as well as the rail and substructure is associated with these factors through the transition functions. An important assumption is the dependence of the transfer function only on the rail and vehicle design and independence from the train speed, levels of roughness and other transition functions. This assumption is quite controversial, while assuming the linearity of occurring phenomena. The basis for determining the transition function is the simultaneous measurement of the sound pressure level at a distance of $7.5 \mathrm{~m}$ from the track axis at a height of $1.25 \mathrm{~m}$ and acceleration of vertical rail vibration. Another approach is to measure the sound pressure in the near field at a distance of 1.75 from the rail at the height of the rail head and to search for the transfer function between vibration and the sound pressure level in the near field.

As part of the Shift2Rail project (Horizon 2020) $[1,20]$, the Roll2Rail project tested and compared a number of known and newly proposed methods based on vibration measurements, beamforming, transfer function analysis and wave signature extraction. However, none of the tested methods gave completely satisfactory results, although the results confirmed some generally known relationships - the dominance of acoustic energy emissions from the track in the low frequency range, while in the higher frequencies the dominance of noise emissions from the train is enhanced, with these relationships additionally dependent are from train speed. Therefore, as part of this work, an attempt was made to extract distinctive features in the acoustic signal generated during train pass-by, associated with the track and with the passing-by train, for various types of passing-by units.

All tests carried out as part of the thesis [19] were conducted on the same section, on two tracks separated by a platform. As the basic criterion for the differentiation of both signals, the spectral density of the recorded signal was adopted, looking for features with low variability associated with the track and features with greater variability that can be attributed to passing-by trains.

\section{ACOUSTIC INVESTIGATIONS}

\subsection{Research object}

All tests were carried out on the same section of the track - at the Kraków - Batowice station in two measuring sections - one section outside the platform (basic measurements), the other at platform height. In the second section, the platform screening effect of the acoustic signal generated by the rail was used. The passing-by units were three types of trains - Pendolino, Stadler and TLK (Fig. 1).

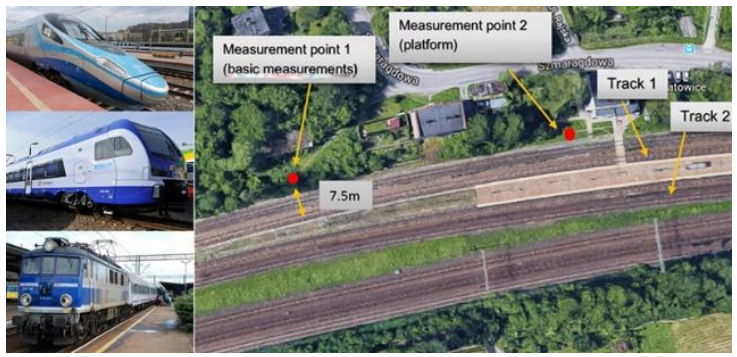

Fig. 1. Train types tested (left side from the top of Pendolino, Stadler and TLK) and place of measurement (right side)

All trains are equipped as standard with disc brakes with maximum travel speeds from $160 \mathrm{kph}$ (Stadler and TLK) to $250 \mathrm{kph}$ (Pendolino).

Train speed was calculated by measuring the pass-by time at a particular distance. To check whether provided calculations were correct, the mobile application "SpeedClock" was used. It is important to notice that both methods were estimations. Train travel speeds on the tested section were limited to approx. $120 \mathrm{kph}$, however individual journeys took place at different speeds from approx. $50 \mathrm{kph}$ to $120 \mathrm{kph}$. Examined track was in a good condition, with ballast, pre-tensioned concrete sleepers and rails on washers fixed with elastic clamps.

The measurement points were located $7.5 \mathrm{~m}$ from the track 1 and $17 \mathrm{~m}$ from the track 2 and were about $60 \mathrm{~m}$ away from the nearest buildings.

\subsection{Measurement methodology}

The acoustic signal from a passing-by train was recorded using the ZOOM H6 recorder in WAVE format with a sampling frequency of $96 \mathrm{kHz}$, while the sound pressure level was recorded using the SVAN 959 analyser. The microphones of both instruments were set at a height of $1.2 \mathrm{~m}$ above ground level at the basic distance from the axis of the first track equal to $7.5 \mathrm{~m}$. Both measuring instruments were located next to each other with microphones directed towards the rails and placed on tripod. The SVAN 959 analyser recorded the dynamic spectrum of the acoustic signal in $1 / 3$ octave 
bands with a time resolution of $100 \mathrm{~ms}$ in the $10 \mathrm{~Hz}$ to 20 $\mathrm{kHz}$ band. The WAVE signal recorded on ZOOM device after initial processing in the AUDACITY software was further postprocessed in MATLAB R2018a, using the Signal Processing Toolbox (analysis and spectral moments as well as parameters of the result spread in $1 / 3$ octave bands).

Distinctive output parameters were adopted arbitrarily, and they resulted from the physical features of the phenomenon described in the introduction, useful in separating the signal from the rail and wheel.

They were:

- $\quad$ sound pressure levels in $1 / 3$ octave bands in the range of $10 \mathrm{~Hz}$ to $20 \mathrm{kHz}$ and their standard deviations during train passing-by,

- spectral moments from zero to fourth order including central normalized moments as well as skewness and kurtosis [13]

Spectral moment of the $m$-th order [2], together with the implementation for SPL, is defined according to the general relationship (1)

$M(m)=\sum_{k=1}^{n}|G(k)|\left(f_{k}\right)^{m}=10 \log \left(\sum_{k=1}^{n} 10^{0,1 L_{k}} f_{k}^{m}\right)$

Where: $m$-order of the spectral moment, $m=0,1,2,3$ ..., $\mathrm{G}(\mathrm{k})$ - spectrum power in the $k$-th frequency band, $k=$ $1,2, \ldots, 31$ - number of consecutive $1 / 3$ octave band frequencies from $20 \mathrm{~Hz}$ to $20 \mathrm{kHz}, L_{k}$ - sound pressure level in the $i$-th frequency band

The $m$-order normalized spectral moment was calculated according to the relationship (2)

$$
M_{u}(m)=\frac{\sum_{k=1}^{n}|G(k)|\left(f_{k}\right)^{m}}{M_{0}}
$$

Where $\mathrm{M}_{0}$ - zero order spectral moment (acoustic signal power). This moment is used as a quantity normalizing higher order moments. After performing normalization using zero moment, the moments of higher orders transfer information about the shape of the spectrum, not about its level.

Normalized central $m$-order spectral moments was calculated according to the relationship (3)

$$
M_{u c}(m)=\frac{\sum_{k=1}^{n}|G(k)|\left[\left(f_{k}-M_{u}(1)\right]^{m}\right.}{M_{0}}
$$

Where $M_{u}(1)$ - normalized spectral moment of the first order (centre of gravity of the spectrum)

$3^{\text {rd }}$ order normalized central moment (skewness) is a measure of spectrum asymmetry with respect to its centre of gravity and normal distribution, whereas $4^{\text {th }}$ order moment, divisible by the square of the $2^{\text {nd }}$ order central moment is a measure of spectrum flattening (kurtosis) and is calculated using formula (4)

$$
\text { Kurtosis }=\frac{M_{u c}(4)}{\left[M_{u c}(2)\right]^{2}}
$$

The assessment of the usefulness of the above parameters was carried out using hierarchical cluster analysis, using the STATISTICA software.

An important parameter used in cluster analysis, allowing the identification of similarity and differences between the examined objects (distinctive features) is distance. The greater the distance between objects, the more different they transfer information about the phenomenon under study. In the case of an attempt to aggregating parameters derived from the track and vehicle, the Chebyshev distance was used, based on the absolute value of the maximum difference between the two values (x,y), described by the relationship (5).

$$
d(x, y)=\max \left|x_{i}-y_{i}\right|
$$

The Ward method was chosen as the hierarchical grouping method using the Chebyshev distance measure, based on estimating the distance between similar objects based on analysis of variance. The method is based on minimizing the sum of squares of standard deviations within communities, and the value used to obtain this value is the ESS (Error Sum of Squares) parameter (6).

$$
E S S=\sum_{i=1}^{k}\left(x_{i}-\bar{x}\right)^{2}
$$

Where $x_{i}$ - value of the parameter used to group the $i^{\text {th }}$ object unit in relation to a given criterion, $\bar{x}$ - average value, $k$ - number of objects in the grouped set

All measurements were carried out in June 2019, average wind speed 2 to $4 \mathrm{~m} / \mathrm{s} \mathrm{NW}$ and NE, temperature 26 to $29 \mathrm{C}$ degree [9]

\subsection{Experimental research results}

In total, over a dozen registrations of each type of train were made, however, for further analysis, some were rejected, mainly due to other disturbances or unusual passage. The examples of LEQ spectra of the tested train types are shown in Figure 2.

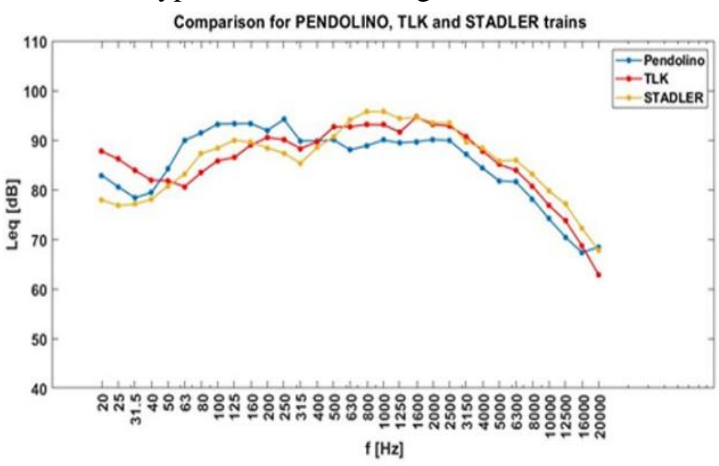

Fig. 2. The average spectra LEQ in $1 / 3$ octave bands during pass-by trains Pendolino, TLK and Stadler

In Fig. 2 the difference between the Pendolino spectrum and the spectra of TLK and Stadler trains that are showing high similarity, is noticeable. For all the records, the spectral analyses were performed with spectral moments for each one-second pass-by section.

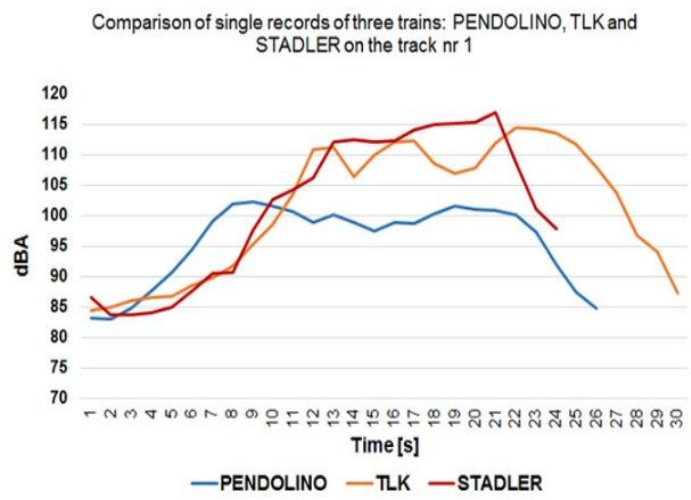

Fig. 3. Comparison of time charts for A-weighted sound level during pass-by Pendolino, TLK and Stadler trains.

It was the first step, the aim of which was to check the variability of the adopted features during the pass-by 
and their dispersion in relation to these parameters determined for the SEL or LEQ level, for flat part of the pass-by.-Exemplary diagrams of A-weighted SPL during pass-by of the trains Pendolino, TLK and Stadler, also including moments just before and just after the pass-by, are shown in Fig. 3.

The dispersion of features during the pass-by is varied, the largest for TLK trains, the least for Pendolino, but they were not significant enough to analyse each pass-by separately for each second, so spectral moments and dispersion were determined for further analysis sound pressure levels in $1 / 3$ octave bands of the entire passage of the vehicle. Nevertheless, these results were used to assess the suitability of spectral moments as distinctive features, analysing their dispersion during TLK train pass-by, as shown in the rest of the work in Fig. 9

A comparison of the spectra from the TLK train passing-by at a speed of about $50 \mathrm{kph}$ and $100 \mathrm{kph}$ is shown in Fig.4.

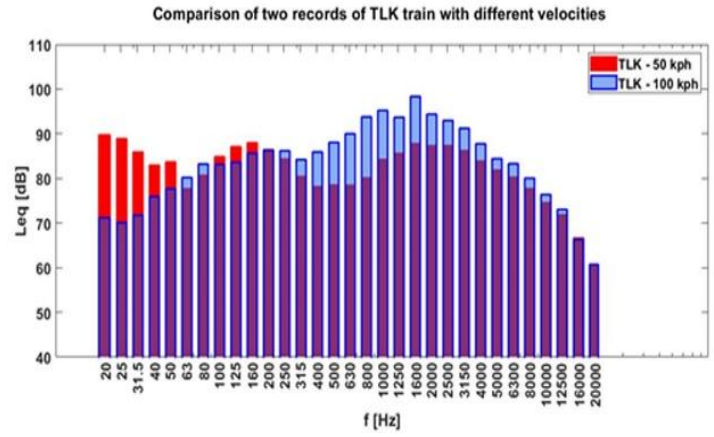

Fig. 4. The average spectra in $1 / 3$ octave bands for passing-by TLK train with two speeds $-50 \mathrm{kph}$ and $100 \mathrm{kph}$.

Whereas a comparison of pass-by spectra of TLK and Pendolino trains on track 1 and track 2 (partially shielded through the platform) is shown respectively in Fig. 5 and Fig. 6.

Increased sound pressure level in bands up to $1 \mathrm{kHz}$ from pass-by TLK train on track 1 clearly indicate that these sounds are shielded through the platform from such train pass-by on track 2 (Fig.5). For Pendolino train passby, this trend is barely noticeable (Fig.6). Differences in sound pressure levels in the higher frequency range can be treated as a characteristic of a given train pass-by.

The variability of LEQ level spectrum for passing-by of the tested train types is shown in Figure 7.

For both trains Pendolino and Stadler, the spread of sound pressure levels in $1 / 3$ octave bands is much smaller than for TLK train pass-by.

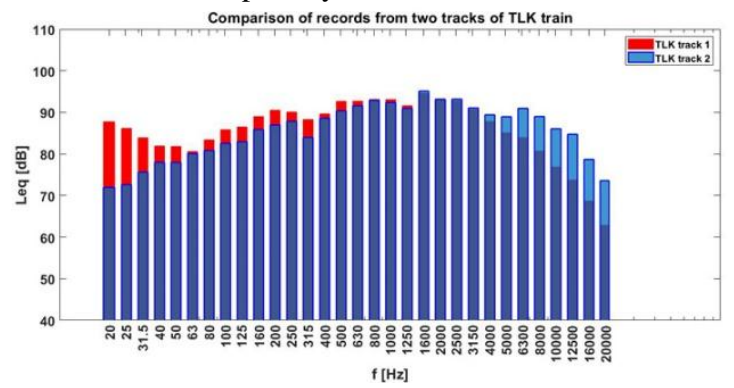

Fig.5. The average sound pressure level in $1 / 3$ octave bands from TLK train pass-by on track 1 and track 2 for $1 / 3$ octave bands.

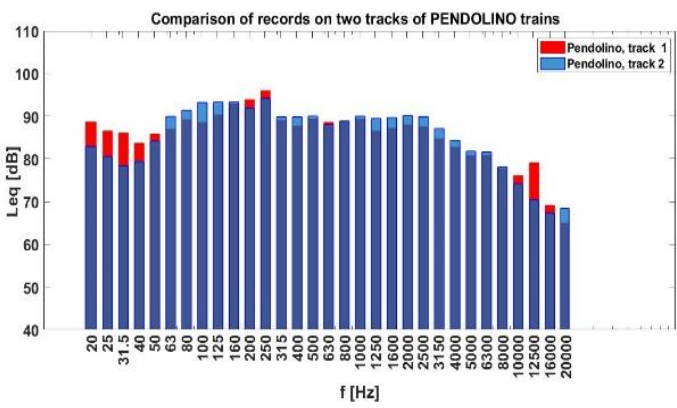

Fig. 6. The average sound pressure level in 1/3 octave bands from Pendolino train pass-by on track 1 and track 2 for $1 / 3$ octave bands.
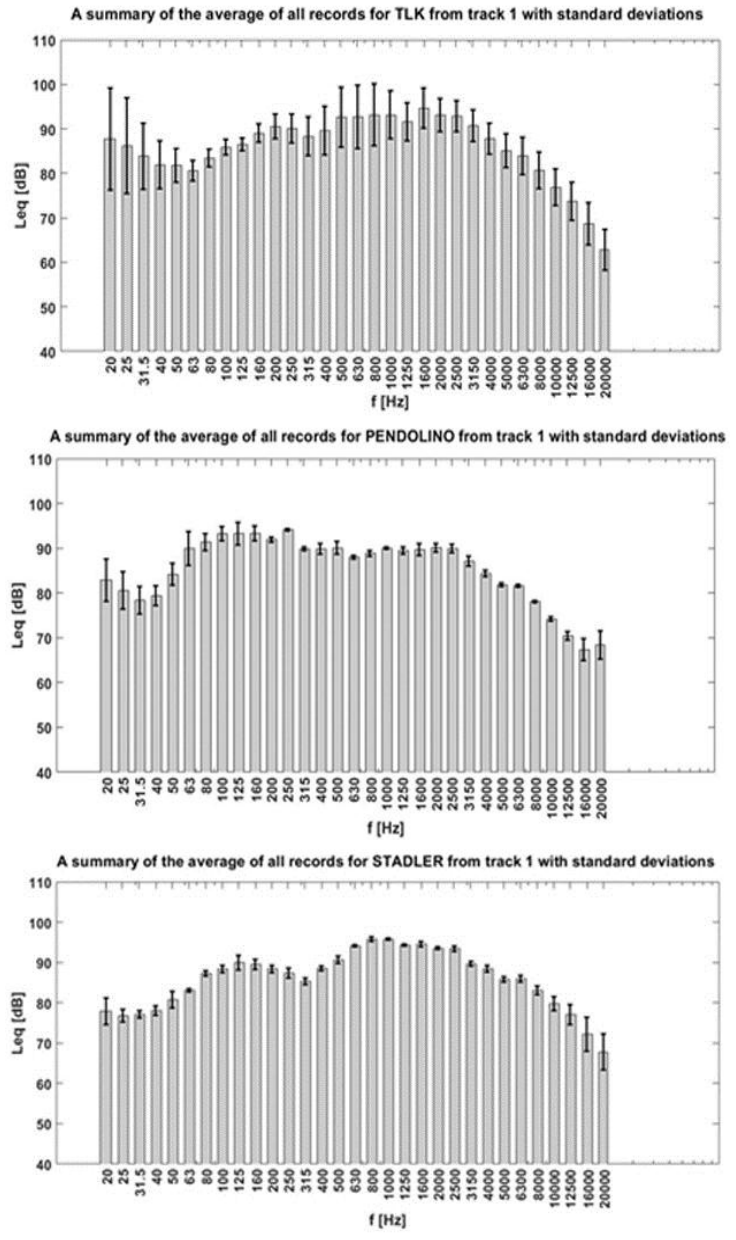

Fig. 7. The average spectra with standard deviation in $1 / 3$ octave bands for all passing-by trains - TLK, Pendolino and Stadler.

At the same time, Pendolino pass-by are characterized by a slightly larger spread at low frequencies (up to $160 \mathrm{~Hz}$ ) and upper frequency $(16 \mathrm{kHz}$ and $20 \mathrm{kHz}$ ) bands, while Stadler train pass-by have slightly higher dispersion only in bands above $10 \mathrm{kHz}$.

TLK train pass-by are characterized by much larger spreads in low bands up to $50 \mathrm{~Hz}$ and middle bands between $315 \mathrm{~Hz}$ and $1600 \mathrm{~Hz}$, with a clearly marked minimum spreads in the bands from $80 \mathrm{~Hz}$ to $200 \mathrm{~Hz}$. The results presented above indicate strongly different train compositions and technical condition of TLK trains, an additional factor was the varied speed of travel, which has a large impact on the level of spectral density in the middle and upper bands, which is well illustrated in Figure 4. 
In the above results it is difficult to directly indicate the small variability of the characteristics of the recorded acoustic signal that could be attributed to rails and the greater variability of the characteristics that could be attributed to passing-by trains.

Nevertheless, certain tendencies are noticeable - in the case of TLK trains, clearly lower spreads in the band attributed to rails and sleepers, similar though weaker trends can be observed in Pendolino crossings. Reduced spreads in the $50 \mathrm{~Hz}-400 \mathrm{~Hz}$ bands, i.e. in the range assigned to rails and sleepers, and higher spreads in the range assigned to the wheels and running gears, i.e. 500 $\mathrm{Hz}$ to $6.3 \mathrm{kHz}$, are shown in Fig. 8 .

So that the spread of spectral moments can be easily compared, they were normalized to the maximum value. The analysis of their spread in all three groups of trains indicates large spreads of kurtosis, partly also of the zero moment, which indicates different acoustic energies of the journeys, associated with different speeds, as in Fig. 9.

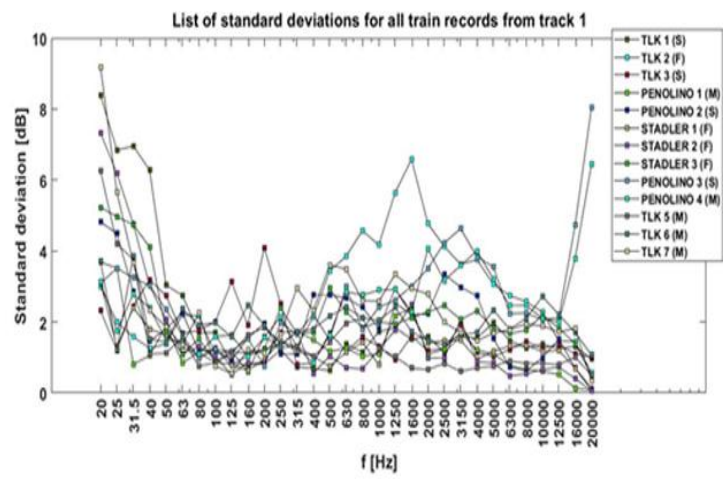

Fig. 8. Standard deviations of LEQ levels in 1/3 octave bands from all train types

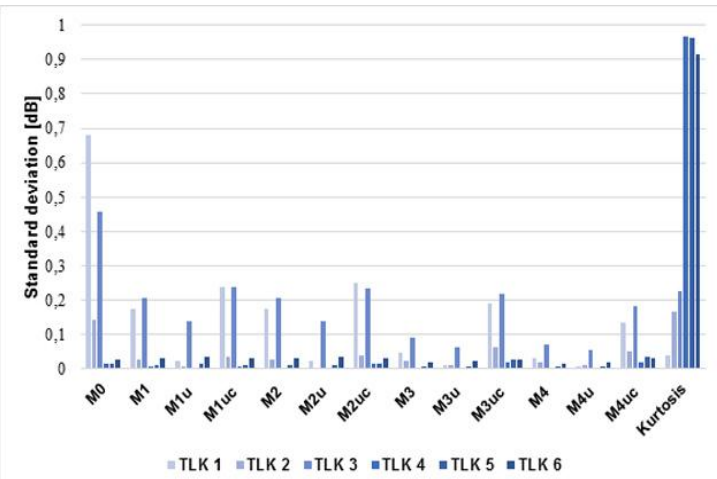

Fig. 9. Standard deviation of spectral moments of TLK pass-by trains. $M O$ - zero order spectral moment (SM), $M 1-1^{\text {st }}$ order SM, $1^{\text {st }}$ order normalized SM, MIuc $-1^{\text {st }}$ order normalized central SM. Consecutive numbers in the abbreviations of the moment names indicate the order of the spectral moments from 1 to 4 .

\section{AGGREGATING OF DISTINCTIVE}

Analysis of the results in the previous chapter, based on the physical characteristics of the phenomenon and confirmed literature data, show some possibilities of using them to differentiate sources of noise generated during train travel. Cluster analysis was adopted as an objective tool for aggregating the features $[6,16]$. It was assumed that the features related to the track and features related to the wheel and the running gear will be aggregated separately. The STATISTICA software was used for this purpose. After verifying the various combinations of both the aggregating methods in dendrograms and the definition of the distance between parameters, the Ward method and the Chebyshev distance were finally chosen, the application of which most faithfully represents a cluster of small and large standard deviations.

As shown in Figure 10 in the case of TLK trains, two groups of distinctive features of standard deviations in $1 / 3$ octave bands can be clearly distinguished - in the low frequency range (associated with the track) and higher frequencies associated with the wheels and the chassis. A similar tendency can be observed in the analysis of the aggregating of features of spectral moments shown in Figure 11.

Cluster analysis for the remaining train groups shows similar trends, both in terms of the standard deviation features and the features of spectral moments, as in Fig.10 and Fig.11.

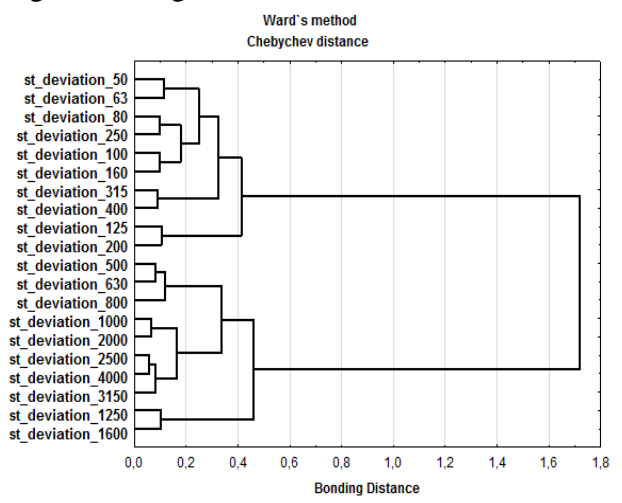

Fig. 10. Cluster analysis of standard deviations for passing-by TLK trains

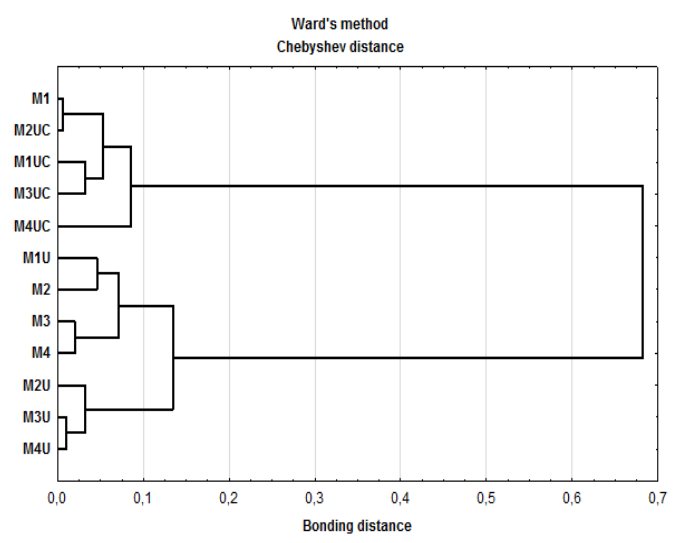

Fig. 11. Cluster analysis of spectral moments for passing-by TLK trains

\section{CONCLUSIONS}

To analyse and evaluate the possibility of differentiating the features of the acoustic signal, a number of measurements of Pendolino, TLK and Stadler trains were carried out on the same track section. Spectral moments ranging from zero to fourth order moments and the spread of results in $1 / 3$ octave bands, characterized by standard deviation, were assumed as distinctive features. As an objective measure of the grouping of parameters "belonging" to the track and the vehicle was adopted cluster analysis made using the Ward method and Chebyshev distance. 
The obtained results show the real possibilities of separating the distinctive features of the acoustic signal from the rail and track and the part of the signal connected with the wheel and the running gear. However it should be remembered, that these signals (features) overlap each other, and their relationships are non-linear, which can be seen at different speeds. Therefore, when attempting to quantify both parts of the signal, it is necessary to measure additionally rail and sleeper vibrations with simultaneous measurement of the acoustic signal at the height of the rail head. This will enable more efficient and useful the assessment of the sources of emitted railway noise extractions of the features of the acoustic signal generated by the rail and track.

An additional increase in the efficiency of differentiating such signals should be possible in the case of tests carried out on sections of different but known technical condition and with a constant controlled speed of passage of the tested rolling stock. However, such research requires support from PLK and PKP carriers.

\section{ACKNOWLEDGMENTS}

The project was financed by the Polish Ministry of Science and Higher Education [project No. 16.16.130.942].

\section{REFERENCES}

1. Arteaga IL. Rolling noise in road and rail transportation systems. Internoise 2019, Madrid, June 16-19.

2. Benoit CJ. Phys. Condens. Matter4 3125, The spectral moments method. 1992.

https://iopscience.iop.org/article/10.1088/09538984/4/12/010/pdf

3. Burdzik R, Nowak B, Młyńczak J, Deuszkiewicz P. Anaysis of the detection and crossing signalig system in safety terms, Diagnostyka 2016; 17(4):65-72.

4. Eichenlaub $\mathrm{Ch}$, Lutzenberger $\mathrm{S}$, Stegemann B, Czolbe Ch. A road test on acoustic wheel rougness measurement, Conference Proceedings. Interonoise 2016.

5. Hanson D, Jiang J, Bruce Dowdell, Richard Dwight. Curve Squeal: Causes, Treatments and Results, Australia 2014.

6. Jain AK, Murty MN, Flynn PJ. Data clustering: a review. ACM Comput Surv. Article in ACM Computing Surveys, 1999. http://citeseerx.ist.psu.edu/viewdoc/download?doi=10 1.1.853.5409\&rep=rep1\&type $=$ pdf

7. Janssens MHA, Dittrich MG, Beer FG, Jones CJC. Railway noise measurement method for pass-by noise, totlal effective roughness, transfer functions and track spatial decay. Journal of Sound and Vibration. 2006; 293:1007-1028.

8. Kohrs T, Kirchner KR, Fast D, Vallesspin A, Sapena J, Garcia AG, Martner O. Sound propagation and distribution around typical tran carbody structures. Conference Proceedings, Euronoise 2018.

9. Kukulski B, Wszołek T, The research on impulsive events in railway noise generated during passage through a railroad switch. /Archives of Acoustics, 2017; 42(3):441-447. https://dx.doi.org/10.1515/aoa2017-0046.

10. Letourneaux Fabien, Olivier Coste, Cyril Mellet, and Pascal Fodiman. Environmental Railway Noise: a Source Separation Measurement Method for Noise
Emissions of Vehicles and Track. In Forum Acusticum. Sewilla, 2002.

11. Majchrowicz J. Differentiation of railway noise sources originating from the track and suspension system. Master thesis, Kraków, 2019.

12. Thompson DG. Squicciarini J, Zang Artega IL, Zea E, Dittrich M, Jansen E, Arcas K, Cierco E, Magrans FX, Malkoun A, Iturritxa E, Guiral A, Stangl M, Schlainzer G, Lopez BM, Chaufor C, Wandell J. Assessment of masurent-based methods for separating wheel and track contributions to railway rolling noise. Applied Acoustics. 2018; 140:48-62. https://doi.org/10.1016/j.apacoust.2018.05.012

13. Thompson D. Railway noise and vibration: mechanism, modelling and means of control. Elsevier. Oxford, 2009.

14. Verheijen E, Paviotti M. VTN. A validated method to separate track and vehicle noise and to assess noise reduction measures. In World Congress Railway, Research. Edinburgh, 2003.

15. Vogel F, Holm S, Ole Christian Lingjirde. Spectral moments and time domain representation of photoacoustic signals used for detection of crude oil in produced water. Oslo, Norwegia, 2001.

16. Wszołek T, Tadeusiewicz R. Extraction of the vector of distinctive features for the acoustic signal from corona in overhead power lines, Archives of Acoustics. 2005;30(4):237,240.

17. Wszołek T. Cumulative Industrial Noise Impact on the Environment. Archives of Acoustics, Vol.42, No 2, 169-174 (2017)

18. Wu TX, Thompson DJ. On rolling noise generation due to wheel/track parametric excitation. Journal of Sound and Vibration. 2006; 293: 566-574 https://doi.org/10.1016/j.jsv.2005.08.041

19. Zea E, Artega IL. Simplified wave signature extraction method for rail contribution estimations. Conference Proceedings, Euronoise 2018.

20. Zea E, Manzari L, Artega IL, Squicciarini G, Thomson D. Separation of track contribution to passby noise by near-field array techniques. International Conress of Acoustics, Buenos Aires 5-9 September 2016, Paper ICA2016-813.

21. ISO 3095:2013. Acoustics - Railway applicationsMeasurement of noise emitted by railbound vehicles.

\section{Received 2019-07-25}

Accepted 2019-11-26

Available online 2019-11-28

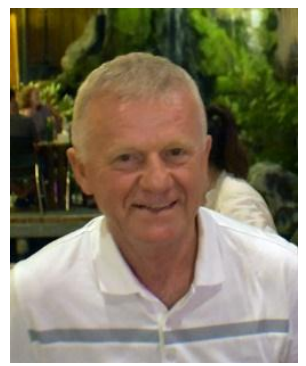

Dr hab inż. Tadeusz WSZOLEK, prof. nadzw. AGH, Dr Sc. Eng., an associate professor at $\mathrm{AGH}$ University of Science and Technology in Krakow. Department of Mechanics and Vibroacoustics. His current research is focused on signal processing and vibroacoustic measurements and diagnostics, noise modelling and environmental monitoring.

Author of over almost two hundred scientific publications and conferences papers. Member of Polish Acoustical Society. 


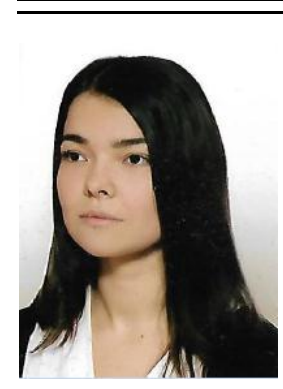

Mgr inż. Justyna

MAJCHROWICZ, M. Sc., Eng.

Her interests of current researches and analyses are the topics broadly connected with the environmental noise, especially the railway noise. The provided simulations include the overall pass by noise calculations. Strongly interested in structural analyses of machines based on FEM, mainly connected with stress and fatigue. 